\title{
GnRH agonists and antagonists decrease the metastatic progression of human prostate cancer cell lines by inhibiting the plasminogen activator system
}

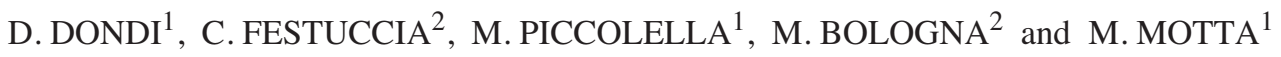 \\ ${ }^{1}$ Department of Endocrinology, Center of Endocrinological Oncology, University of Milano; \\ ${ }^{2}$ Department of Experimental Medicine, University of L'Aquila, Italy
}

Received July 25, 2005; Accepted September 20, 2005

\begin{abstract}
Prostate cancer (PCa) growth initially depends on circulating androgens. Gonadotropin-releasing hormone $(\mathrm{GnRH})$ agonists are currently used for the treatment of PCa. However, after an initial responsiveness to hormonal deprivation, PCa progresses and metastasizes. Recently, also GnRH antagonists have been used for clinical trials in patients with PCa and the results seem promising. The components of the plasminogen activator (PA) system (urokinase-type PA, uPA; PA inhibitors, PAI-1/2; uPA receptor, uPAR) have been implicated in the local degradation of the extra-cellular matrix (ECM) and PCa progression. The aim of this study was to test the possible effects of the treatment with an agonist (Leuprolide, GnRH-A) and an antagonist (Cetrorelix, GnRH-ANT) of $\mathrm{GnRH}$ on the expression and activity of UPA and PAI-1 in the conditioned media of DU145 and PC3, two PCa androgenindependent cell lines. The involvement of the PA system in the control of cellular migration was also investigated. The results obtained in DU145 and PC3 cells show that both GnRH-A and GnRH-ANT: i) inhibit cell proliferation; ii) significantly decrease the enzymatic activity and the secretion of UPA; iii) significantly increase the protein levels of PAI-1; iv) induce a significant decrease of the migratory and invasion PCa capabilities. This study suggest that GnRH analogues exhibit not only an antiproliferative effect, but also an antimetastatic action exerted through the inhibition of the activity of PA system and might provide a rational basis for the development of clinical strategies for those tumours that progress towards an androgen-independent condition characterized by a higher metastatic potential.
\end{abstract}

Correspondence to: Dr Donatella Dondi, Department of Endocrinology, Center of Endocrinological Oncology, University of Milano, Via Balzaretti 9, 20133 Milano, Italy

E-mail: donatella.dondi@unimi.it

Key words: gonadotropin-releasing hormone (GnRH) agonist, GnRH antagonist, urokinase-type plasminogen activator (uPA), prostate cancer, metastatic progression

\section{Introduction}

Prostate cancer $(\mathrm{PCa})$ growth initially depends on circulating androgens (1). Gonadotropin-releasing hormone (GnRH) agonists, either alone, or in combination with antiandrogens, represent the most widely used current hormonal treatment. The antitumoural effect of GnRH agonists is based on their ability to suppress the activity of the pituitary-testicular axis, and therefore, to reduce testosterone production and secretion. However, GnRH agonists induce, at the beginning of treatment, an initial stimulation of LH and FSH (2). For this reason, GnRH antagonists have been developed. These compounds, while maintaining the ability to inhibit the activity of the pituitarygonadal axis by binding to the pituitary GnRH receptors (GnRHR), do not induce the so-called 'flare-up' phenomenon, the intracellular cascade of events evoked by the natural hormone or GnRH agonists (3). The last generations of GnRH antagonists have already been successful in clinical trials of phase I and II.

More recently, GnRH has been shown to be produced also by endocrine-related tumours, where it acts as a growth inhibitory factor $(4,5)$. In particular, it has been reported that a large portion of human PCa specimens as well as PCa cell lines express both mRNA and binding sites for GnRH (6). The activation of GnRHR by $\mathrm{GnRH}$ analogues induces a significant decrease of cancer cell proliferation either androgendependent (7) or androgen-independent (8), through signal transduction mechanisms different from those observed in pituitary cells $(9,10)$.

However, after an initial responsiveness, advanced $\mathrm{PCa}$ almost invariably progresses to a condition of androgenindependence generally associated with a higher proliferation rate and an increased invasiveness, mainly at lymphonode and bone levels (11). Little information is available on the molecular mechanisms that are involved in the control of the metastatic properties of PCa cells.

The malignant process of tumour invasion and metastasis requires the extensive disruption of cell-cell and cell/extracellular matrix (ECM) contacts as well as the degradation of ECM components that represent the physical barrier in the direction of migration/invasion. Overexpression and/or inappropriate regulation of proteolytic activity often occur(s) in neoplasia. Moreover, invasion of cancer is supported by a 
controlled degradation of ECM by proteases released from cancer cells. Many findings strongly suggest that the plasminogen activators (PAs) are involved in PCa progression and invasion $(12,13)$. In mammals, two molecular forms of PAs have been described: the urokinase-type PA (uPA) and the tissue-type PA (tPA). Both PAs catalyze the same reaction (the conversion of plasminogen to plasmin), but tPA is thought to be more important in vascular fibrinolysis, whereas uPA is considered to be involved in tissue remodelling. The serine protease uPA, initially secreted by malignant cells as an enzymatic inactive single chain pro-enzyme (pro-uPA), is cleaved into the active two chain 50-52 kDA form of uPA by binding with the cell-surface urokinase-type uPA receptor (UPAR). Hence receptor-bound, uPA promotes plasminogen conversion in plasmin, activating a cascade of proteinases culminating in the dissolution of the tumour matrix and the basement membrane (14). Overexpression of components of the uPA-system in non-metastatic cells enhances metastasis; inhibition of uPA and/or of the UPA/uPAR interaction prevents or reduces metastasis in animal models $(15,16)$. Specific inhibitors such as the plasminogen activator inhibitor-1 (PAI-1) represent important regulators of the biology of the uPA system. PAI-1 is $52 \mathrm{kDa}$ glycoprotein secreted by many cancer cells that binds uPA with the subsequent formation of an inactive complex (15). The PA system may also regulate activities that do not depend on the function of uPA as a proteinase. The complex uPA/uPAR may regulate cellular adhesion and migration by association to the extracellular domains of integrins, or by binding directly to vitronectin $(17,18)$.

PCa cells vary in terms of net PA activity (19). This variability positively correlates with the in vitro invasive activity of $\mathrm{PCa}$ cell lines and with their in vivo metastatic potential $(20,21)$. The two human androgen-independent $\mathrm{PCa}$ cell lines DU145 and PC3, express high levels of uPA, while the androgen-dependent PCa cell line LNCaP is devoid of detectable uPA (22).

The aim of this study was to examine whether a GnRH agonist (Leuprolide, GnRH-A) as well as a GnRH antagonist (Cetrorelix, GnRH-ANT) may interfere with the proteolytic activity of the PA proteases released from DU145 and PC3 cells. To this purpose, uPA and PAI-1 activities and levels have been evaluated in the cell culture media of the two human androgen-independent PCa cell lines. Moreover, it has also been analysed whether both the GnRH analogues might affect not only the proliferation, but also the migration and invasiveness of PCa cells.

\section{Materials and methods}

GnRH analogues. The GnRH agonist Leuprolide [(pGlu ${ }^{1-}$ $\mathrm{His}^{2}-\mathrm{Trp}^{3}-\mathrm{Ser}^{4}-\mathrm{Tyr}^{5}$-D-Leu ${ }^{6}-\mathrm{Leu}^{7}-\mathrm{Arg}^{8}-\mathrm{Pro}^{9}-\mathrm{NHC}_{2} \mathrm{H}_{5}$ ] GnRH; GnRH-A] was kindly provided by Takeda (Osaka, Japan); the GnRH antagonist Cetrorelix [SB-75; (ac-D-Nal ${ }^{1}-\mathrm{D}-\mathrm{Cpa}^{2}$ D-Pal ${ }^{3}-\mathrm{Ser}^{4}-\mathrm{Tyr}^{5}$-D-Cit ${ }^{6}-\mathrm{Leu}^{7}-\mathrm{Arg}^{8}-\mathrm{Pro}^{9}-\mathrm{D}-\mathrm{Ala}^{10}-\mathrm{NH}^{2}$ ) GnRH; GnRH-ANT] was kindly provided by Zentaris (Frankfurt, Germany). GnRH analogues were dissolved in serum-free RPMI-1640 medium (Biochrom KG, Berlin, Germany).

Cell culture. The PCa androgen-independent cells DU145 and PC3 were obtained from the American Type Culture
Collection (Rockville, MD). Cells were routinely grown in RPMI-1640 medium (Biochrom KG), supplemented with 5\% fetal bovine serum (FBS) that was obtained from Gibco BRL, Grand Island, NY), glutamine $(2 \mathrm{mM})$, penicillin $(100 \mathrm{U} / \mathrm{ml})$, streptomycin $(100 \mu \mathrm{g} / \mathrm{ml})$ and geneticin $(25 \mu \mathrm{g} / \mathrm{ml})$ in a humidified atmosphere of $5 \% \mathrm{CO}_{2}: 95 \%$ air at $37^{\circ} \mathrm{C}$.

Cell growth studies. DU145 and PC3 cells were plated at a density of 500 cells $/ \mathrm{cm}^{2}$ in $10-\mathrm{mm}$ dishes in RPMI-1640 medium supplemented with $5 \%$ FBS; cells were allowed to attach and start growing for 2 days and the seeding media were then changed. Cells were daily treated (for 4 days) with graded doses $\left(10^{-10}-10^{-6} \mathrm{M}\right)$ of the GnRH agonist (Leuprolide, GnRH-A) or the GnRH antagonist (Cetrorelix, GnRH-ANT). At the end of the treatments, cells were harvested and counted using a hemocytometer; cell viability was determined by trypan blue dye exclusion after staining for $5 \mathrm{~min}$ at room temperature. Similar treatments were used to analyse whether GnRH analogues might influence the migration and the invasiveness of the PCa DU145 and PC3 cells.

The results of three separate experiments are presented as the mean \pm SD. Each experimental group was performed in triplicate. Statistical analysis was performed by one-way ANOVA followed by Tukey's multiple comparison tests. $\mathrm{P}<0.05$ was considered statistically significant.

PA assay and uPA enzymatic immuno assays (EIA). Plasminogen activator assays were carried out in 96-well flat-bottomed multi-well plates (NUNC) using H-D-Val-Leu-Lys-pNA (S2251, Sigma) as substrate of plasmin as described previously (22). Briefly, $24 \mathrm{~h}$ conditioned media of DU145 and PC3 cultures, grown onto 24-well plates in the presence or in the absence of graded doses $\left(10^{-8}-10^{-6} \mathrm{M}\right)$ of GnRH-A or GnRHANT, were incubated in assay buffer (100 mM Tri-HCl, $\mathrm{pH} 8.8$, $0.5 \%$ Triton $\mathrm{X}-100)$ with plasminogen $(2.8 \mu \mathrm{g})$ for $4 \mathrm{~h}$ at room temperature. Plasmin activity assay was started by the addition of substrate $(\mathrm{S} 2251,50 \mu \mathrm{g})$ in a final volume of $100 \mu \mathrm{l}$. The change in A405 nm was monitored with a Titertek multiscan reader (Bio-Rad). Enzymatic activities were determined following subtraction of values found for conditioned media incubated without plasminogen. Results are presented as Plough Units, determined using a standard plasmin or urokinase preparation (Sigma). Plasmin inhibitor (D-Val-Phe-Lys CMK, Sigma) was used to confirm PA dependence of substrate degradation.

Previous studies performed in our laboratories demonstrated that the in vitro uPA secretion from DU145 and PC3 cells follows an exponential kinetic curve between 8 and $24 \mathrm{~h}$, reaching a plateau at $48 \mathrm{~h}$; for this reason, we studied the uPA secretion in the cell culture media after 8 and $24 \mathrm{~h}$ from the treatments. Enzymatic activity of uPA was measured by Enzymatic immuno-adsorbent assay by coating 96 flat bottomed microtiter plates with $20 \mathrm{mg} / \mathrm{ml}$ of anti-uPA antibody as previously described (22). The uPA activity was measured in 8- and 24-h conditioned media of DU145 and PC3 cultures grown onto 24-well plates in the presence or absence of graded doses $\left(10^{-8}-10^{-6} \mathrm{M}\right)$ of GnRH-A or GnRH-ANT. Enzymatic activity was measured (uPA-bound to the antibody-coated plates) using both plasmin and urokinase colorimetric substrate (Calbiochem, EMD Bioscience Inc., La Jolla, CA, USA). 
Corresponding cells were collected and counted in a Neubauer chamber (Hausser, Blu Bell, PA, USA) to normalize the enzymatic activity of uPA of the conditioned media; the results are expressed as $\mathrm{ng} / \mathrm{mg}$ protein.

Zymography for plasminogen activators. Samples of conditioned media from DU145 and PC3 cells treated for 8 or $24 \mathrm{~h}$ with graded doses $\left(10^{-8}-10^{-6} \mathrm{M}\right)$ of GnRH-A or GnRHANT were separated by electrophoresis under non-reducing conditions using $7.5 \%$ SDS-PAGE co-polymerized with $0.1 \%$ lactose-free casein and $15 \mu \mathrm{g} / \mathrm{ml}$ human plasminogen. Following electrophoresis, gels were washed three times for $5 \mathrm{~min}$ in a solution of $50 \mathrm{mM}$ Tris $\mathrm{pH} 7.5$ containing $2 \%$ Triton X-100 and rinsed three times in $50 \mathrm{mM}$ Tris $\mathrm{pH} 7.5$. Gels were incubated in a buffer containing $50 \mathrm{mM}$ Tris, $0.1 \%$ Triton X-100 and $0.02 \% \mathrm{NaN}_{3}, \mathrm{pH} 7.5$ for $4 \mathrm{~h}$ at $37^{\circ} \mathrm{C}$ in a humidified environment. Enzyme activity was detected as a negatively stained region following staining in $0.1 \%$ solution of coomassie blue in a mixture of methanol:acetic acid:water (3:1:6) and de-stained in the same solution without dye. Controls were performed using SDS-PAGE co-polymerized with casein without plasminogen and/or using serine protease inhibitors added in the incubation buffer. For uPA analysis, we used a goat polyclonal antibody against uPA (C20, Santa Cruz) diluted 1:400. Corresponding cells were collected and counted in a Neubauer chamber (Hausser, Blu Bell) to normalize the enzymatic activity of the conditioned media. The zymography allows the direct and simultaneous detection of the major plasminogen activator form (uPA, 52-50 kDa) with its enzymatic activity; the uPA activity in this blot is shown by clear zones of proteolysis on a dark background of non-degraded stained casein.

Immunoblot analysis. Samples of conditioned media from DU145 and PC3 cultures treated for 8 or $24 \mathrm{~h}$ with graded doses $\left(10^{-8}-10^{-6} \mathrm{M}\right)$ of GnRH-A or GnRH-ANT were separated by electrophoresis under non-reducing conditions and transferred to Hybond paper. Non-specific binding sites were blocked for $1 \mathrm{~h}$ in 5\% non-fat dried milk in a Tris-buffer containing $20 \mathrm{mM}$ Tris and $137 \mathrm{mM} \mathrm{NaCl}(\mathrm{pH}$ 7.6). Blots were then incubated with goat polyclonal antibody against PAI-1 (C20, Santa Cruz) diluted 1:100 for $1 \mathrm{~h}$. The staining was visualised by a secondary anti-goat IgG antibody linked to horseradish peroxidase (Amersham International, Aylesbury, UK).

Migration and invasion assay. Briefly, cell migration assay was performed using a 48 well-Boyden chamber (Neuroprobe, Inc., Concorezzo, Milan, Italy) containing $8 \mu \mathrm{m}$ polycarbonate filters. Filters were coated on one side with $50 \mu \mathrm{g} /$ $\mathrm{ml}$ laminin, rinsed once with PBS, and then plated in contact with the lower chamber containing $200 \mu 1$ of RPMI1640 medium. DU145 and PC3 cells pre-treated for 4 days with GnRH-A $\left(10^{-6} \mathrm{M}\right)$ or GnRH-ANT $\left(10^{-6} \mathrm{M}\right)$ were collected, washed twice with $\mathrm{PBS}$, rinsed in complete medium and incubated at $37^{\circ} \mathrm{C}$ for 30 min to reconstitute the membrane structures. Cells were then added in aliquots (75.000 cells/ $50 \mu \mathrm{l}$ ) to the top of each chamber and allowed to migrate through coated filters for $4 \mathrm{~h}$. At the end of the incubation, the chamber was disassembled and non-migrated cells on the upper membrane surface were removed with a
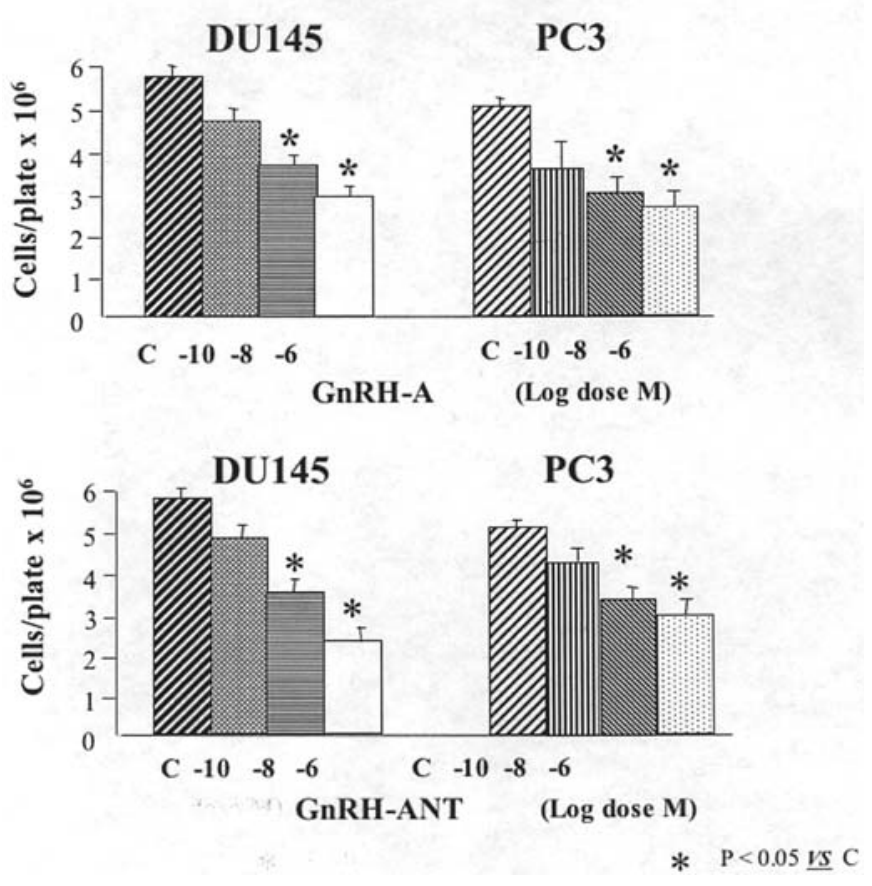

Figure 1. Effect of the treatment with GnRH-A or GnRH-ANT on the proliferation of DU145 and PC3 cells. Cells were treated for 4 days with graded doses $\left(10^{-10}-10^{-6} \mathrm{M}\right)$ of GnRH-A or GnRH-ANT. At the end of the treatment, cells were collected and counted by haemocytometer. The results are averages $( \pm \mathrm{SD}$, bars) from three independent experiments. C, control cells

cotton swab. The migrated cells attached on the lower membrane surfaces were fixed and stained with Diffquik (Biomap, Italy) for $20 \mathrm{~min}$ at room temperature. Migrated cells were counted at a $\mathrm{x} 40$ magnification in standard optical microscopy.

Invasion assay was performed in invasion chambers (Becton-Dickinson, Bedford, MA) contain a membrane coated with Matrigel $^{\mathrm{TM}}$, a layer of extracellular matrix. The digestion of Matrigel allowed the migration of cancer cells. Briefly, DU145 and PC3 cells pre-treated for 4 days with GnRH-A $\left(10^{-6} \mathrm{M}\right)$ or GnRH-ANT $\left(10^{-6} \mathrm{M}\right)$ were collected, and $500 \mu 1$ of cell suspension (75.000 cells) were added to trans-well inserts with an $8 \mu \mathrm{m}$ pore size coated with Matrigel. In the lower compartment of the invasion chamber, $5 \%$ FBS contained medium was added as chemo-attractant. After a 22-h incubation period at $37^{\circ} \mathrm{C}$, cells that passed through the filter into the bottom wells were fixed, stained with Diffquik (Biomap, Italy) and counted at a $\mathrm{x} 40$ magnification in standard optical microscopy.

Each individual experiment of migration and invasion was performed in triplicate. Statistical analysis was performed by one-way ANOVA followed by Tukey's multiple comparison tests. $\mathrm{P}<0.05$ was considered statistically significant. The results are expressed as a percentage of migrated cells vs control cells.

\section{Results}

GnRH analogues decrease cell proliferation in PCa cells. This experiment has been performed to clarify whether, in our experimental conditions, Leuprolide (GnRH-A) and 
Table I. Effect of the treatment with GnRH-A or GnRHANT on the total PA activity in DU145 and PC 3 cells.

\section{Total PA (mU/mg protein)}

DU145

PC3

\begin{tabular}{lll}
\hline Controls & $4.1 \pm 0.5$ & $8.4 \pm 0.2$ \\
GnRH-A $\left(10^{-8} \mathrm{M}\right)$ & $2.7 \pm 0.4$ & $6.3 \pm 0.6$ \\
GnRH-A $\left(10^{-6} \mathrm{M}\right)$ & $1.8 \pm 0.2^{\mathrm{a}}$ & $5.4 \pm 0.2^{\mathrm{a}}$ \\
GnRH-ANT $\left(10^{-8} \mathrm{M}\right)$ & $3.1 \pm 0.4$ & $5.3 \pm 0.2^{\mathrm{a}}$ \\
GnRH-ANT $\left(10^{-6} \mathrm{M}\right)$ & $2.1 \pm 0.1^{\mathrm{a}}$ & $4.7 \pm 0.3^{\mathrm{a}}$
\end{tabular}

The results are averages $( \pm \mathrm{SD}$, bars $)$ from three independent experiments. ${ }^{\mathrm{a}} \mathrm{P}<0.05$ vs controls.

Cetrorelix (GnRH-ANT) might affect the proliferation of DU145 and PC3 cells.

Cells were treated daily (for 4 days) with graded doses of GnRH-A or GnRH-ANT. The treatment of PCa cells with both GnRH-A and GnRH-ANT resulted in a dose-dependent inhibition of tumour cell growth (Fig. 1). Both GnRH analogues were significantly effective from $10^{-8}$ to $10^{-6} \mathrm{M}$. It is of interest to note that, while the treatment with the highest dose $\left(10^{-6} \mathrm{M}\right)$ of GnRH-A seems to produce a quite similar inhibitory effect on the proliferation of both DU145 (49 $\pm 6 \%$ of inhibition) and PC3 $(45 \pm 8 \%$ of inhibition) cells, the treatment with the same dose of GnRH-ANT appears to be more effective in DU145 (57 $\pm 8 \%$ of inhibition) with respect to PC 3 cells $(42 \pm 8 \%$ of inhibition).

GnRH analogues inhibit the PA system activity. To determine the effectiveness of the treatment with GnRH analogues on the PA system activity, we evaluated the effect of GnRH-A and GnRH-ANT on the total enzymatic activity of plasminogen
(PA) by using a chromogenic assay for plasmin and S2251 as substrate. The assay was performed on conditioned media of DU145 and PC 3 cells treated for $24 \mathrm{~h}$ in the presence or in the absence of graded doses of GnRH-A or GnRH-ANT. PA secreted from both DU145 and PC3 cells was significantly decreased following the treatment with the highest dose $\left(10^{-6} \mathrm{M}\right)$ of both GnRH-A and GnRH-ANT (Table I). The dose of $10^{-8} \mathrm{M}$ of GnRH-ANT decreased the secretion of PA only from PC 3 cells, being the same dose ineffective on DU145 (Table I).

To recognize which form of PA is more influenced by the treatment with $\mathrm{GnRH}$ analogues, we studied, by enzymatic immuno-absorbant assay (EIA), the presence of the urokinase plasminogen activator (uPA) enzyme in the conditioned media of DU145 and PC 3 cells treated for 8 and $24 \mathrm{~h}$ in the presence or in the absence of graded doses of GnRH-A or GnRH-ANT. Interestingly, both the $\mathrm{PCa}$ cells released the uPA protein (measured as $\mathrm{ng} / \mathrm{mg}$ protein) into the culture medium, even if the basal levels of secreted uPA in DU145 cells were significantly lower than those observed in PC3 cells at the same time interval (Fig. 2).

The treatment with the dose of $10^{-6} \mathrm{M}$ of GnRH-A (Fig. 2) significantly reduced, at the times considered ( 8 and $24 \mathrm{~h}$ ), the uPA secretion in both the PCa cells. The lower dose $\left(10^{-8} \mathrm{M}\right)$ of the $\mathrm{GnRH}$ agonist was also efficacious in inhibiting the $24 \mathrm{~h}$ secretion of UPA in PC3 cells, while it was ineffective at any time considered on the secretion of uPA from DU145 cells.

An inhibition of uPA production was also observed when the PCa cells were treated with the GnRH-ANT (Fig. 3). The highest dose $\left(10^{-6} \mathrm{M}\right)$ of GnRH-ANT significantly inhibited the uPA secretion in both the PCa cells; on the other hand, only DU145 and not PC3 cells responded to the inhibitory effect of the lowest dose (10-8 M) of GnRH-ANT at $24 \mathrm{~h}$ (Fig. 3).

To further characterize the uPA enzymatic activity in PCa cells, we performed zymogram analysis on the same

\section{DU145}
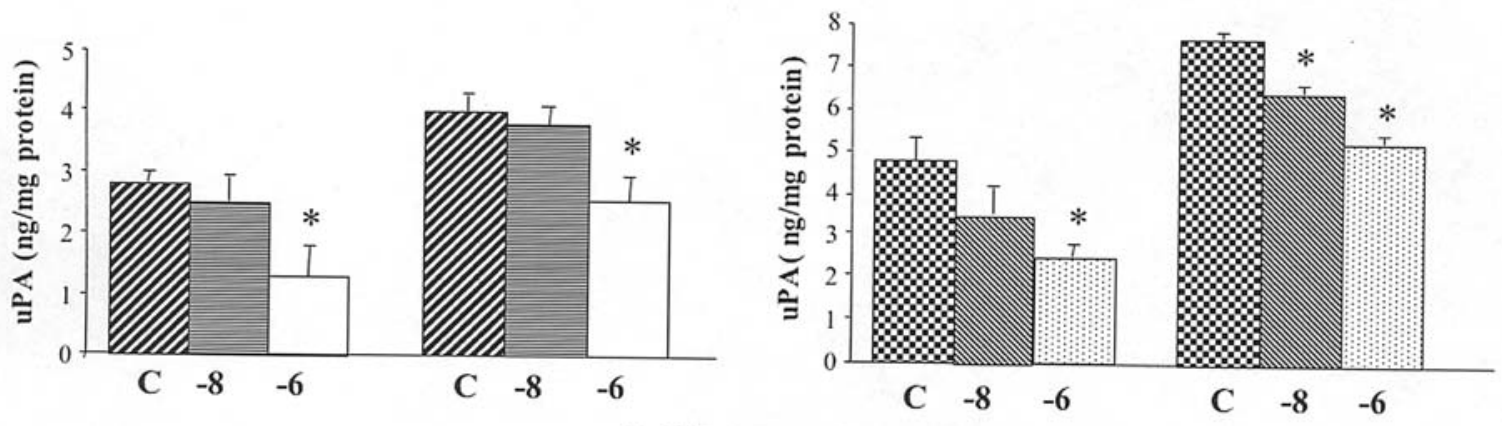

$8 \mathrm{~h}$

$24 \mathrm{~h}$

GnRH-A (Log dose M)

$8 \mathrm{~h}$

$24 \mathrm{~h}$

Figure 2. Effect of GnRH-A on the uPA production. The assay was performed on conditioned media collected from DU145 and PC3 cells either untreated (C) or treated (for 8 and $24 \mathrm{~h}$ ) with graded doses $\left(10^{-8}-10^{-6} \mathrm{M}\right)$ of GnRH-A. The evaluation of the presence of uPA was performed by using an enzymatic immunoabsorbent assay (EIA). 
DU145

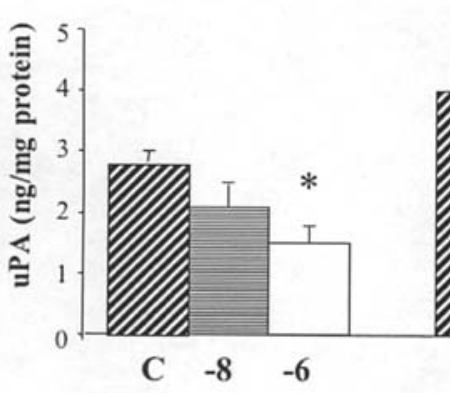

8 h

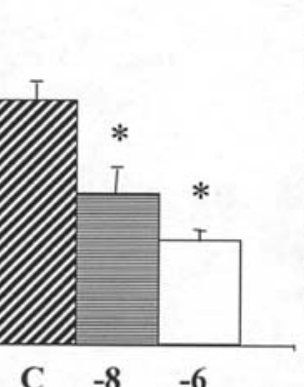

GnRH-ANT (Log dose M)

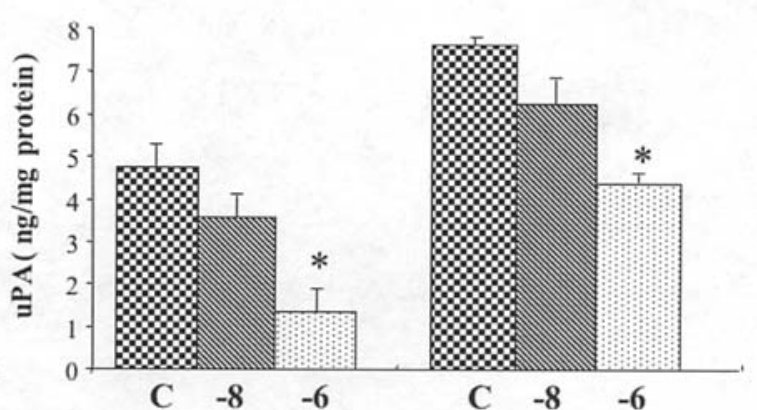

$8 \mathrm{~h}$
PC3

$24 \mathrm{~h}$

Figure 3. Effect of GnRH-ANT on the uPA production. The assay was performed on conditioned media collected from DU145 and PC3 cells either untreated (C) or treated (for 8 and $24 \mathrm{~h}$ ) with graded doses $\left(10^{-8}-10^{-6} \mathrm{M}\right)$ of GnRH-ANT. The evaluation of the presence of uPA was performed by using an enzymatic immuno-absorbent assay (EIA).

A

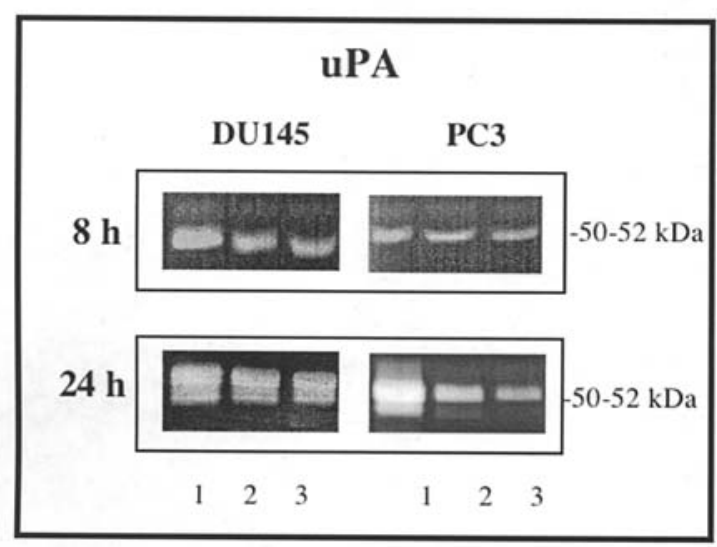

B

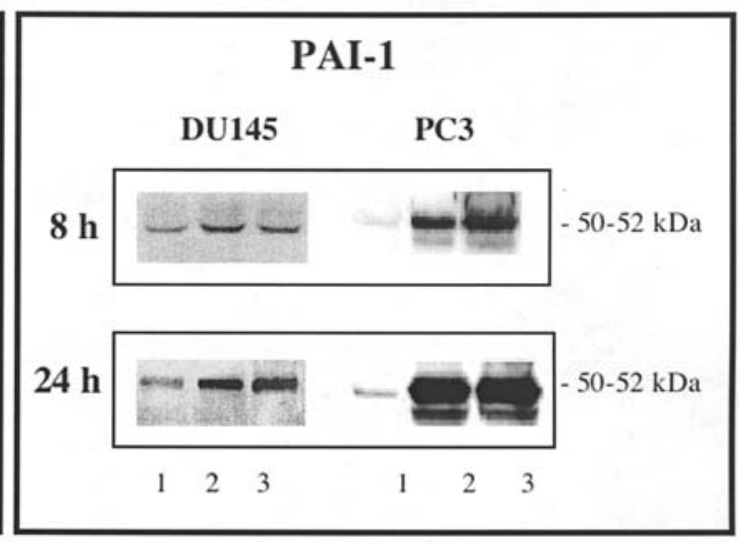

Figure 4. Representative gelatin zymography of uPA (panel A) and Western blot for PAI-1 (panel B) performed on the conditioned media of DU145 and PC3 cells untreated (lane 1) or treated for 8 and $24 \mathrm{~h}$ with graded doses of GnRH-A $\left(10^{-8} \mathrm{M}\right.$, lane $2 ; 10^{-6} \mathrm{M}$, lane 3$)$.

conditioned media tested for the enzymatic activity. Fig. 4 (panel A) clearly shows that in both DU145 and PC3 cells, GnRH-A induced a marked and dose-dependent decrease of the proteolysis associated to the $52-50 \mathrm{kDa}$ isoform of uPA, which is more evident after $24 \mathrm{~h}$ of incubation (lanes 2 and 3 ). To fully characterize the effects of GnRH-A on the uPA system in PCa cells, we analysed, in the same samples, the presence of the uPA inhibitor PAI-1 by Western blot (Fig. 4, panel B). PAI-1 is co-secreted with the uPA by both PCa cell lines. After GnRH-A treatment (lanes 2 and 3) there is, at the times considered ( 8 and $24 \mathrm{~h}$ ), a clear and dose-dependent induction of the PAI- 1 in both DU145 and PC3 cells.

The effects of GnRH-ANT on uPA in both DU145 and PC3 cells demonstrated (Fig. 5, panel A) that the antagonist decreased in a dose-dependent manner the proteolysis associated to UPA at all the time considered (lanes 2 and 3); at the same time, the GnRH-ANT increased the PAI-1 (lanes 2 and 3 ) in both DU145 and PC3 cells (Fig. 5, panel B).

GnRH analogues inhibit the migration and invasiveness of PCa cells. The PA system is known to be deeply implicated in the process of invasiveness and metastasis of $\mathrm{PCa}$ cells. Therefore, it was of interest to study whether the inhibitory effects of the two GnRH analogues on the PA system activity previously observed, might interfere with the ability of DU145 and PC3 cells to migrate and invade. For the following experiments, the dose of $10^{-6} \mathrm{M}$ was selected because of its efficacy on both PCa cell types in every experiment performed and at each time interval considered. DU145 and PC3 cells, pre-treated for 4 days with GnRH-A 
A

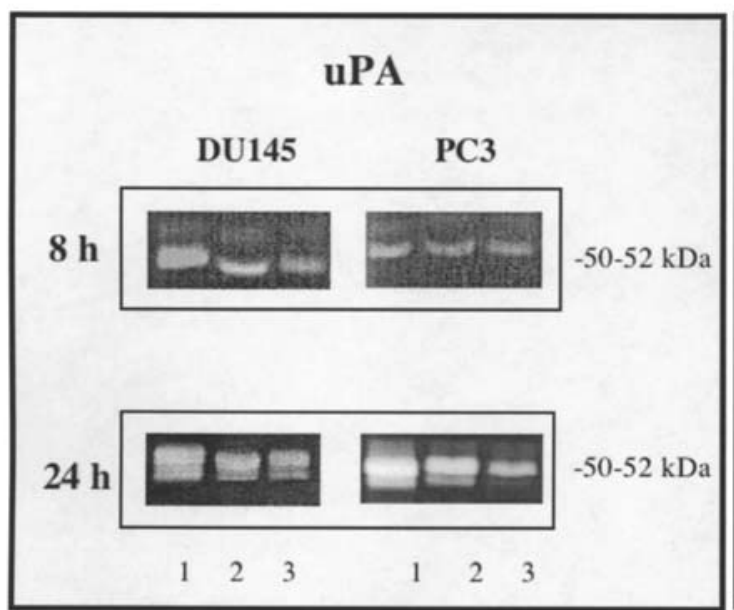

B

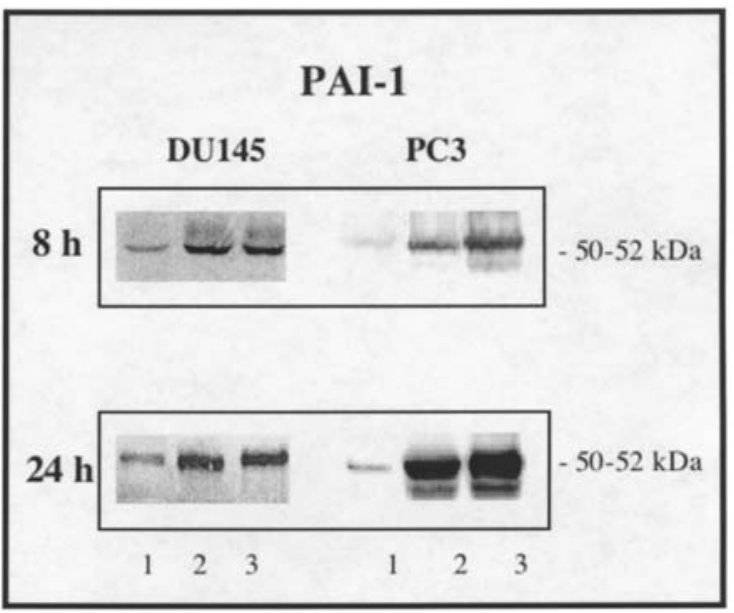

Figure 5. Representative gelatin zymography of uPA (panel A) and Western blot for PAI-1 (panel B) performed on the conditioned media of DU145 and PC3 cells untreated (lane 1) or treated for 8 and $24 \mathrm{~h}$ with graded doses of GnRH-ANT $\left(10^{-8} \mathrm{M}\right.$, lane $2 ; 10^{-6} \mathrm{M}$, lane 3$)$.
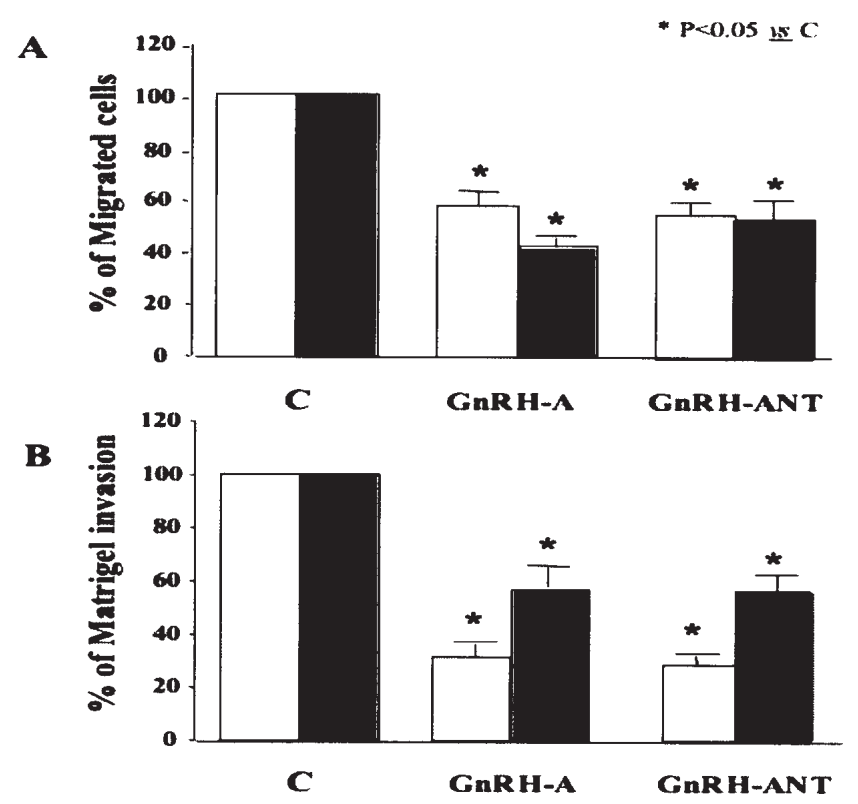

Figure 6. Effect of the treatment with GnRH-A $\left(10^{-6} \mathrm{M}\right)$ or GnRH-ANT $\left(10^{-6} \mathrm{M}\right)$ on the haptotaxis induced by laminin (panel A) and on Matrigel invasion (panel B) in DU145 ( $\square$ ) and PC3 (ロ) cells. Cells were pre-treated for 4 days with GnRH-A or GnRH-ANT. At the end of the treatment, cells were harvested, counted and seeded in Boyden's chamber (A) or in Matrigel invasion chamber $(B)$. The results are expressed as percentage $( \pm \mathrm{SD}$, bars) from three independent experiments. $\mathrm{C}$, control cells.

or GnRH-ANT were then collected and transferred to the migration and invasion assays. Fig. 6 (panel A) shows that PCa cells responded to both the GnRH analogues decreasing their migration through membranes coated with laminin in a Boyden chamber analysis. In particular, GnRH-A exposure significantly reduced the migratory activity of DU145 and PC 3 from $100 \%$ down to $58 \pm 6 \%$ and $42 \pm 4$ respectively, while GnRH-ANT significantly inhibited the two PCa cells from $100 \%$ down to $55 \pm 5 \%$ and $53 \pm 8 \%$, respectively (Fig. 6, panel A).
The effects of GnRH analogues have then been evaluated on the ability of DU145 and PC3 cells to invade a Matrigel matrix. PCa pre-treated cells (4 days) with GnRH-A (10-6 M) or GnRH-ANT $\left(10^{-6} \mathrm{M}\right)$ were transferred to Matrigel invasion chambers. Fig. 6 (panel B) indicates that the GnRH-A exposure significantly reduced the invasiveness of both DU145 (from $100 \%$ down to $31 \pm 6 \%$ ) and PC3 (from $100 \%$ down to $58 \pm 7 \%$ ) sublines through the Matrigel barrier. Also GnRH-ANT $\left(10^{-6} \mathrm{M}\right)$ significantly inhibited the invasiveness of DU145 $(28 \pm 5 \%)$ and PC3 $(57 \pm 6 \%)$ cells.

\section{Discussion}

The present study shows that the treatment with both the GnRH agonist Leuprolide (GnRH-A), and the GnRH antagonist Cetrorelix (GnRH-ANT), inhibits, as expected, the proliferation of the androgen-independent PCa cells DU145 and PC3; moreover, the treatment with both GnRH-A and GnRH-ANT decreases the expression and the activity of uPA and, at the same time, increases PAI-1 in the conditioned media of DU145 and PC 3 cells. Both the GnRH analogues reduce the metastatic potential of $\mathrm{PCa}$ cell lines.

The GnRH-ANT exerts a marked antiproliferative activity on $\mathrm{PCa}$ cell lines, indicating that this compound might behave as antagonist at pituitary level and as agonist at the level of the tumour. In addition, when administered simultaneously, GnRH-ANT did not antagonise the inhibitory action of GnRH-A and no summation or potentiation of the inhibitory effect exerted separately by each compound was observed in PCa cells (data not shown), as already reported previously (23). The mechanisms by which GnRH-ANT produces the same antiproliferative effect than the agonist, observed in a number of human malignant tumours such as breast, ovary and endometrium (24), however, remain unknown. It might be related to different molecular characteristics between the GnRHR present at pituitary level, where the receptor is coupled to the $\mathrm{Gq} /{ }_{11}$-PLC intracellular system of events $(9,10)$, and that expressed at the tumour 
level, where the receptor is coupled to the Gi protein $(25,26)$. A second plausible explanation might lie in the possible, but not yet detected, existence of a GnRH type II receptor in $\mathrm{PCa}$ tissues; this second hypothesis is proposed by Gründker et al (24) for endometrial and ovarian cancers. However, further studies are needed to clarify this issue in PCa cells.

The novel finding of this study, observed to our knowledge for the first time in PCa cells, resides in the inhibitory effect exerted by both GnRH agonists and antagonists on the activity of the PA system, one of the most important protease networks controlling degradation of ECM matrix $(12,13)$.

We observed that both GnRH-A and GnRH-ANT significantly decrease the secretion as well as the enzymatic activity of the serino-protease uPA in the conditioned media of androgen-independent PCa cells. Concomitantly, we demonstrated that both the GnRH analogues induce a marked increase of the protein levels of PAI-1, the inhibitor that inactives UPA through the formation of a complex (15). It is well known that high uPA levels indicate a poorer prognosis (27) and that the inhibition of uPA and/or of the uPA/uPAR interaction prevents or reduces metastasis $(15,16)$. Little information is available on the interactions between the GnRH analogues and the uPA system in cancer cells. McDonnel and Murdoch (28) described that GnRH did not affect the secretion of uPA by SKOV-3 ovarian cancer cells; however, this discrepancy might depend on the experimental conditions adopted (native GnRH vs GnRH analogues, type of cancer cell lines utilized, etc.).

The activation of the PA system is also known to promote diverse processes that require cell migration in vivo, which is a prerequisite for invasion and metastasis. The present observation that GnRH analogues, besides modulating the PA system activity, antagonise the metastatic behaviour of both DU145 and PC3 cells by decreasing their capacity to invade a reconstituted matrix and to migrate in response to a haptotactic stimulus gives support to the involvement of the PA system on the anti-metastatic effect of these drugs. Yates and colleagues (29) have shown that, in DU145 cells, Cetrorelix increases the cell-cell adhesion complex molecules E-cadherin, $\alpha$ and $\beta$ catenin and p120 through a downregulation of the EGFR signalling. In addition, the interaction between GnRH and PA system has already been reported in other experimental models: GnRH modulates the invasive capacity of human trophoblastic cells and human decidual stromal cells through the control of the activity of uPA and PAI-1 (30,31).

To date, the mechanism(s) by which GnRH analogues regulate uPA/PAI-1 expression has not been determined. One possible mechanism is through the GnRH-mediated increase of crucial transcription factor such as AP-1 (32). Multiple AP-1 binding sites have been detected in the promoter regions of both the UPA and PAI-1 human genes (33). The activation of transcription factors such as AP-1 might be induced by mitogen-activated protein kinases (MAPKs). Preliminary experiments performed in our laboratory showed that both GnRH-A and GnRH-ANT induce the phosphorylation of ERK1/2 in DU145 and PC3 cells; this effect seems to be specific, because it is prevented by a pre-treatment with the MAPK/ERK kinase inhibitor PD98059 (Piccolella et al, unpublished data). The phosphorylation of ERK1/2 might be responsible for the activation of several nuclear transcription factors involved in cellular proliferation, migration and invasion processes. To this regard, GnRH agonists are reported to induce apoptosis through both JNK and ERK MAPKs in the nucleus of DU145 cells (34). Recently, Kim and co-workers suggest that the activation of ERK1/2 by GnRH-II subsequently phosphorylates Elk-1 as a down-stream pathway in ovarian cancer cells (35).

In conclusion, the present study indicates that both $\mathrm{GnRH}$ agonists and antagonists induce, in addition to their antiproliferative effect, an inhibition of the activity and efficacy of the PA system in PCa cells. These effects are obtained through the inhibition of the production and the activity of uPA concomitantly with the increase of its inhibitor, PAI- 1 . The two GnRH analogues are also able to decrease the migratory capabilities and the invasiveness of the PCa cells.

The fact that both GnRH agonists and antagonists are effective in inhibiting the production of proteases controlling the degradation of cell-cell and cell-matrix interactions in some steroid-unresponsive cancer cell lines might provide a rational basis for the development of clinical strategies for those tumours that progress towards an androgen-independent condition characterized by a high metastatic potential.

\section{Acknowledgements}

FIRST 2003, FIRST 2004, Center of Endocrinological Oncology supported this study.

\section{References}

1. Cunha GR, Donjacour AA, Cooke PS, Mee S, Bigsby RM, Higgins SJ and Sugimura Y: The endocrinology and developmental biology of the prostate. Endocrine Rev 8: 338-357, 1987.

2. Conn PM and Crowley WFJ: Gonadotropin-releasing hormone and its analogs. Ann Rev Med 45: 391-405, 1994.

3. Huirme JA and Lambalk CB: Gonadotropin-releasing-hormonereceptor antagonists. Lancet 358: 1793-1803, 2001.

4. Emons G, Grundker G, Gunthert AR, Westphalen S, Kavanagh G and Verschraegen C: GnRH antagonists in the treatment of gynecological and breast cancers. Endocr Relat Cancer 10: 291-299, 2003.

5. Harrison GS, Wierman ME, Nett TM and Glode LM: Gonadotropin-releasing hormone and its receptor in normal and malignant cells. Endocr Relat Cancer 11: 725-748, 2004.

6. Halmos G, Arencibia JM, Schally AV, Davis R and Bostwick DG: High incidence of receptors for luteinizing hormone-releasing hormone (LHRH) and LHRH receptor gene expression in human prostate cancers. J Urol 163: 623-629, 2000.

7. Limonta P, Dondi D, Moretti RM, Fermo D, Garattini E and Motta M: Expression of luteinizing hormone-releasing hormone mRNA in the human prostatic cancer cell line LNCaP. J Clin Endocrinol Metab 76: 797-800, 1993.

8. Dondi D, Limonta P, Moretti RM, Marelli MM, Garattini E and Motta M: Antiprolifearative effects of luteinizing hormonereleasing hormone (LHRH) agonists on the human androgenindependent prostate cancer cell line DU 145: evidence for an autocrine-inhibitory LHRH loop. Cancer Res 54: 4091-4095, 1994.

9. Kraus S, Naor Z and Seger R: Intracellular signaling pathways mediated by the gonadotropin-releasing hormone (GnRH) receptor. Arch Med Res 32: 499-509, 2001.

10. Ruf F, Fink MY and Sealfon SC: Structure of the GnRH receptorstimulated signaling network: insights from genomics. Front Neuroendocrinol 24: 181-199, 2003.

11. Gittes RF: Carcinoma of the prostate. N Engl J Med 324: 236-245, 1991.

12. Achbarou A, Kaiser A, Tremblay G, Ste-Marie LG, Brodt P, Goltzman D and Rabbani SA: Urokinase overproduction results in increased skeletal metastasis by prostate cancer cells in vivo. Cancer Res 54: 2372-2377, 1994. 
13. Sheng S: The urokinase-type plasminogen activator system in prostate cancer metastasis. Cancer Met Rev 20: 287-296, 2002.

14. Rabbani SA and Mazar AP: The role of the plasminogen activator system in angiogenesis and metastasis. Surg Oncol Clin N Am 10: $393-415,2001$

15. Sidenius $\mathrm{N}$ and Blasi F: The urokinase plasminogen activator system in cancer: Recent advances and implication for prognosis and therapy. Cancer Metastasis Rev 22: 205-222, 2003.

16. Margheri F, D'Alessio S, Serrati S, Pucci M, Annunziato F, Cosmi L, Liotta F, Angeli R, Angelucci A, Gravina GL, Rucci N, Bologna M, Teti A, Monia B, Fibbi G and Rosso MD: Effects of blocking urokinase receptor signaling by antisense oligonucleotides in a mouse model of experimental prostate cancer bone metastases. Gene Ther 12: 702-714, 2005.

17. Wei Y, Waltz DA, Rao N, Drummond RJ, Rosenberg S and Chapman HA: Identification of the urokinase receptor as an adhesion receptor for vitronectin. J Biol Chem 269: 32380-32388, 1994.

18. Wei Y, Lukashev M, Simon DI, Bodary SC, Rosenberg S, Doyle MV and Chapman HA: Regulation of integrin function by the urokinase receptor. Science 273: 1551-1555, 1996.

19. Heinert G, Kirchheimer JC, Pfluger H and Binder BR: Urokinasetype plasminogen activator as a marker for the formation of distant metastases in prostatic carcinomas. J Urol 140: 1466-1469, 1988.

20. Lyon PB, See WA, Xu Y and Cohen MB: Diversity and modulation of plasminogen activator activity in human prostatecarcinoma cell lines. Prostate 27: 179-186, 1995.

21. Festuccia C, Vicentini C, Firma N, Pasquale ABD, Aceto G, Zazzeroni F, Miano L and Bologna M: Plasminogen activator activities in short-term tissue cultures of benign prostatic hyperplasia and prostatic carcinoma. Oncol Res 7: 131-138, 1995.

22. Festuccia C, Dolo V, Guerra F, Violini S, Muzi P, Pavan A and Bologna M: Plasminogen activator system modulates invasive capacity and proliferation in prostatic tumor cells. Clin Exp Metastasis 16: 513-528, 1998.

23. Limonta P, Pratesi G, Moretti RM, Marelli MM, Motta M and Dondi D: Comments on inhibition of growth of androgenindependent DU-145 prostate cancer in vivo by luteinising hormone-releasing hormone antagonist Cetrorelix and bombesin antagonists RC-3940-II and RC-3950-II, Jungwirth, et al. Eur J Cancer 33: 1141-1148, 1997. Eur J Cancer 34: 1134-1136, 1998.

24. Gründker C, Günthert AR, Westphalen S and Emons G: Biology of the gonadotropin-releasing hormone $(\mathrm{GnRH})$ system in gynecological cancers. Eur J Endocrinol 146: 1-14, 2002.

25. Grundker C, Volker P and Emons G: Antiproliferative signaling of luteinizing hormone-releasing hormone in human endometrial and ovarian cancer cells through $G$ protein alpha(I)-mediated activation of phosphotyrosine phosphatase. Endocrinology 142: 2369-2380, 2001.
26. Limonta P, Moretti RM, Marelli MM and Motta M: The biology of gonadotropin hormone-releasing hormone: role inthe control of tumor growth and progression in humans. Front Neuroendocrinol 24: 279-295, 2003.

27. Miyake H, Harax H, Yamanaka K, Gohji K, Arakawa S and Kamidono S: Elevation of serum levels of urokinase-type plasminogen activator and its receptor is associated with disease progression and prognosis in patients with prostate cancer. The Prostate 39: 123-129, 1999.

28. McDonnel AC and Murdoch WJ: High-dose progesterone inhibition of urokinase secretion and invasive activity by SKOV-3 ovarian carcinoma cells: evidence for a receptor-independent nongenomic effect on the plasma membrane. J Steroid Biochem Mol Biol 78: 185-191, 2001.

29. Yates C, Wells A and Turner T: Luteinising hormone-releasing hormone analogue reverses the cell adhesion profile of EGFR overexpressing DU-145 human prostate carcinoma subline. Br J Cancer 92: 366-375, 2005.

30. Chou CS, Zhu H, Shalev E, MacCalman CD and Leung PC: The effects of gonadotropin-releasing hormone (GnRH)I and II on the urokinase-type plasminogen activator/plasminogen inhibitor system in human extravillous cytotrophoblasts in vitro. J Clin Endocrinol Metab 87: 5594-5603, 2002.

31. Chou CS, MacCalman CD and Leung PC: Differential effects of gonadotropin-releasing hormone I and II on the urokinase-type plasminogen activator/plasminogen activator inhibitor system in human decidual stromal cell in vitro. J Clin Endocrinol Metab 88: 3806-3815, 2003.

32. Wurmbach E, Yuen E, Ebersole BJ and Sealfon SC: Gonadotropin-releasing hormone receptor-coupled gene network organization. J Biol Chem 276: 47195-47201, 2001.

33. Irigoyen P, Munoz-Canoves P, Montero L, Koziczak M and Nagamine Y: The plasminogen activator system: biology and regulation. Cell Mol Life Sci 56: 104-132, 1999.

34. Kraus S, Levy G, Hanoch T, Naor Z and Seger R: Gonadotropinreleasing hormone induces apoptosis of the prostate cancer cells: role of c-Jun NH2-terminal kinase, protein kinase B and extracellular signal-regulated kinase pathways. Cancer Res 64: 5736-5744, 2004

35. Kim K-Y, Choi K-C, Park S-H, Auersperg N and Leung PCK: Extracellular signal-regulated protein kinase, but not c-Jun Nterminal kinase, is activated by type II gonadotropin-releasing hormone involved in the inhibition of ovarian cancer cell proliferation. J Clin Endocrinol Metab 90: 1670-1677, 2004. 